\title{
Japanese researchers rule out gene patents
}

\section{- Stance opposes US, UK positions - Plan to make data freely available}

\section{Osaka}

THE leading scientists in Japan's effort to sequence the genomes of humans and plants say they do not plan to join the United States and Britain in filing patents on their discoveries but will instead publish the data and make it freely available. The various government ministries and agencies involved in genome research have yet to develop a policy on the patenting of genes, and it would be unprecedented for the government to intervene in a scientific decision of this type.

A controversy erupted among genome researchers last year after Craig Venter of the US National Institutes of Health (NIH) filed patent applications for more than 300 cDNA fragments of human genes. Researchers at Britain's Medical Research Council (MRC) initially condemned Venter's move, but the MRC has since decided to file patent applications for more than $1,000 \mathrm{cDNA}$ sequences.

At present, only the Science and Technology Agency, which is expected to play a leading role in Japan's human genome project, has established a small committee of five lawyers to examine the issue of patenting human genes. But the committee is not expected to produce a report for at least a year.

Kenichi Matsubara, who works at the Institute of Molecular and Cellular Biology of Osaka University, says that he will not file patents for the more than 2,000 sequences of human complementary DNA (cDNA) that his group currently has deposited in the DNA databank of Japan in Mishima. Matsubara says he will make the sequences available once he has published the work, which he expects to do soon.

Matsubara says there is no possibility of his decision being reversed by the Japa- nese government. The Ministry of Education, Science and Culture, which funds the Osaka group, leaves it up to individual scientists and their universities to decide whether to file patents.

The Japanese group uses sequencing techniques that are similar to what is done by the NIH team, but the goals of the two teams differ somewhat. Whereas Venter produces partial sequences of genes of unknown function to produce structural maps of the human genome, Matsubara wants to make a 'body map' of human genes that will show where they are expressed in the body and their function.

Leaders of other major genome projects in Japan are taking a similar position to Matsubara. Yuzo Minobe, director of Japan's rice genome project at the National Institute of Agribiological Resources in Tsukuba, says that all results from the multi-million dollar effort to sequence the rice genome will be made freely available and that no patent applications should be filed for rice DNA sequences.

Takashi Yura of Kyoto University, who leads a project to sequence the complete genome of the bacterium Escherichia coli, an organism widely used in the biotechnology industry, says he has "absolutely no intention" of filing patents. His group is preparing to publish a 110-kilobase sequence, and it is sequencing another 250 kilobases out of the total genome of 4,700 kilobases.

There have been rumours in the United States that Eichi Soeda of the Institute of Physical and Chemical Research (RIKEN), whose team is sequencing chromosome 6 of yeast, is planning to patent yeast DNA sequences. But Soeda says he has no intention of doing so with the industrially important organism. David Swinbanks

\section{Betting on rice}

Tokyo

JAPAN's effort to map and sequence the rice genome is moving forward rapidly, thanks largely to a craze among Japanese 'office ladies' for betting on horses. The huge boost in funds will raise its budget to a level comparable in scale to Japan's human genome project.

Last year, the Japanese Racing Association (JRA) - an organization funded by racehorse gambling - decided to put money into Japan's rice genome project (see Nature 353,$99 ;$ 1991). The association predicted it would contribute $\$ 6$ million a year on top of the $\$ 2.7$ million already being spent by the Ministry of Agriculture, Forestry and Fisheries. But in December, JRA boosted its contribution to $\$ 2,000$ million (\$15 million), and the organizers of the project now expect the total annual budget, including government funds, to be at least $¥ \mathbf{2 , 4 0 0}$ million yen (\$18.5 million).

The association donates about 25 per cent of its earnings to government projects, including research. It is flush at the moment because racehorse betting is particularly popular among young office workers. Similar associations for motor boat and bicycle racing also give money to Japanese science, but these sports are not as popular among young Japanese women.

Project organizers expect the current 40-member team from industry and the National Institute of Agribiological Resources to more than double in size over the next several years. The seven-year project is backed by a newly formed association of 160 companies called the Society for Techno-innovation of Agriculture, Forestry and Fisheries (STAFF). Six companies - Mitsui Toatsu Chemicals, Mitsubishi, Kirin, Japan Tobacco, Sanyo Electric, and Hitachi Chemical - are providing researchers for genome analysis and technology development.

The first few years of the project will develop physical and linkage maps of the genome as well as a cDNA catalogue. $\mathrm{Re}$ searchers will move onto mapping chromosomes and isolating useful genes. D.S.

\section{MITI makes its move, cautiously}

JAPAN's powerful Ministry of International Trade and Industry (MITI) is at last taking its first step into genome research.

In a few weeks, the biochemical industry division within MITI will form a committee to coordinate various small projects that involve DNA analysis and to consider a project to sequence the genomes of industrially useful microorganisms. The eventual aim is a permanent government centre for DNA analysis.

MITI has hesitated to join genome research partly because the topic lies in the domain of other ministries but also because industry has shown little interest. And Masahiro Hashimoto, deputy director of the biochemical division, emphasizes that the present initiative is meant to strengthen DNA analysis and is not a genome project. Hashimoto also admits that it may take a "long time" to persuade the Ministry of Finance that such a centre is needed.

The committee will try to coordinate three small MITI projects under the jurisdiction of the biochemical industry division: a project within Japan's huge fifth-generation computer project that is developing computer systems to handle the vast amounts of data arising from genome research (see Nature 345, 467; 1990); the application of nanotechnology, such as the scanning tunnelling microscope, to an analysis of DNA at a new interdisciplinary research centre in Tsukuba (see Nature $\mathbf{3 5 1}$, $90 ; 1991) ;$ and a small project within MITI's huge global environment research programme to isolate and develop photosynthetic microorganisms to absorb carbon dioxide. D.S. 